\title{
Inhibition of the water splitting system by sodium chloride stress in the green alga Chlorella vulgaris
}

\author{
Mostafa M. EL-Sheekh
}

Botany Department, Faculty of Science, Tanta University, 31527 Tanta,Egypt.E-mail: msheekh@dec1.tanta.edu.eg Received: 10/10/2003, Accepted: 09/02/2004

The effect of sodium chloride on the photosynthetic electron transport chain was investigated in the freshwater green alga Chlorella vulgaris. It was found that the rate of oxygen evolution under steady state and flash light conditions diminished by increasing salt concentrations. Salt treatment of cells also decreased the fluorescence and delayed luminescence yields. However, the fluorescence yield was almost completely restored by the addition of an artificial electron donor to the NaCl-treated cells. The oscillation pattern of the thermoluminescence $B$ band as a function of flash number indicated that the $\mathrm{S}_{2} \rightarrow \mathrm{S}_{3}$ transition of the water splitting system is inhibited by $\mathrm{NaCl}$ treatment.

Key words: Chlorella, electron transport, photosystem II, salinity.

Inibição do sistema de fotooxidação da água por estresse com cloreto de sódio na alga verde Chlorella vulgaris: $\mathrm{O}$ efeito do $\mathrm{NaCl}$ na cadeia transportadora de elétrons foi investigado na alga verde Chlorella vulgaris. Observou-se que a taxa de liberação de oxigênio sob condições de equilíbrio e de flash de luz diminuía à medida que se aumentava a concentração de sal. $\mathrm{O}$ tratamento com $\mathrm{NaCl}$ também diminuiu o rendimento da fluorescência e retardou o da luminescência. No entanto, o rendimento da fluorescência foi quase inteiramente restaurado pela adição de um doador artificial de elétrons. O padrão de oscilação da banda de termoluminescência $B$ como função do números de flashes indicou que a transição $S_{2} \rightarrow S_{3}$ do sistema de fotooxidação da água era inibida pelo tratamento com $\mathrm{NaCl}$.

Palavras-chave: Chlorella, fotossistema II, salinidade, transporte de elétrons.

Abbreviations: Chl, chlorophyll; DCMU, 3-(3,4-dichlorophenyl)-1,1-dimethylurea, DCPIP, 2,6-dichlorophenolindophenol; Fm, F0, maximum and constant fluorescence; Fp, yield of fluorescence at transient Fp; Fv, variable chlorophyll fluorescence; MV, methyl viologen; $\mathrm{QA}$, and QB, primary and secondary quinone acceptors of PSII; PS, photosystem

\section{INTRODUCTION}

Salinity of soil and irrigation water is a serious problem in agriculture leading to severe crop losses. It is also considered an important ecological variable in the fresh water and marine environment. Salinity has been suggested as being a controlling factor for blooms of cyanobacteria in estuaries and is considered as one of the major constraints on species diversity and productivity of natural population of algae (Booth and Beardall, 1991; Chen and Plant, 1999). Particularly in estuarine water planktonic algae are often subjected to widely fluctuating salt concentrations (Guillard, 1962; Moisander et al. 2002). Such changes in the salinity of water often affect the growth, metabolism and photosynthesis of phytoplanktons (Moisander et al. 2002; Lartigue et al. 2003). Salt might have a direct effect upon processes involved in electron transport and/or photophosphorylation and result in a decrease in the quantum efficiency of photosynthesis (Seeman and Critchley, 1985). In this connection El-Sheekh and Omar (2002) indicated that ATP is severely affected by salt stress in Chlorella vulgaris, however NADPH was not affected. Other studies (Sharma and Hall, 1991) showed that the light saturating rate of $\mathrm{CO}_{2}$ uptake and maximum quantum yield decreased with increasing salt concentrations in barley and sorghum seedling leaves. Shen and Katoh (1991) working 
with chloroplasts from spinach localized the $\mathrm{NaCl}$ effect at photosystem II. However, there are several studies on the effect of salt stress on microorganisms, particularly in freshwater algae dealing with the inhibitory effect of $\mathrm{NaCl}$ on oxygen evolution, chlorophyll fluorescence, the photochemistry and function of photosystem II. (Joset et al. 1996; Murakami et al. 1997; Gonzales-Moreno et al. 1997; Lu and Vonshak; 1999, Lu and Zhang, 1999; Lu et al. 1999; Lu and Zhang, 2000; Lu and Vonshak, 2002). The work presented here deals with the effect of $\mathrm{NaCl}$ stress on photosynthesis of the freshwater green alga Chlorella vulgaris. Applying the techniques of fluorescence, delayed light emission and thermoluminescence measurements, we localized the inhibitory $\mathrm{NaCl}$ action at the $\mathrm{S}_{2} \rightarrow \mathrm{S}_{3}$ transitions of the water splitting system in photosystem II.

\section{MATERIAL AND METHODS}

Organism and Growth Conditions: Chlorella vulgaris was isolated from a water sample collected from the channels of Nile River in Egypt. Bacterial-free cultures were obtained by using the technique described by EL-Sheekh (1990). The medium used for cultivation was the freshwater algal medium recommended by Kuhl (1962). The cultures were continuously illuminated with fluorescent tubes, incubated at $27^{\circ} \mathrm{C}$ and aerated with a mixture of $95 \%$ air and $5 \% \mathrm{CO}_{2}$. The cells were incubated with different concentrations of $\mathrm{NaCl}$ for $10 \mathrm{~min}$ in the dark before measurements.

Oxygen Evolution Measurements: Oxygen evolution and /or consumption were measured with A Clark-type electrode. The actinic white light was obtained from a $150 \mathrm{~W}$ tungsten lamp. For oxygen evolution under flash light conditions, the algal cells were suspended in $50 \mathrm{mmol} . \mathrm{L}^{-1}$ phosphate buffer $\mathrm{pH}$ 6.5 containing $50 \mathrm{mmol} . \mathrm{L}^{-1} \mathrm{KCl}$. Flash-induced oxygen yield was measured with a Joliot-type electrode. $100 \mu \mathrm{l}$ sample aliquots with a chlorophyll concentration of $70 \mu \mathrm{g}$ chl. $\mathrm{ml}^{-1}$ were illuminated with a sequence of short flashes after $5 \mathrm{~min}$ adaptation in the dark on the surface of the electrode. The flash frequency was $2 \mathrm{~Hz}$.

Fluorescence Induction Measurements: Fluorescence induction transients of the intact algal cells (equivalent to 15 $\mu \mathrm{g}$ chl.ml ${ }^{-1}$ ) were measured after excitation with white light (NARVA, TGL 10619, $10 \mathrm{~W} \cdot \mathrm{m}^{-2}$ ). The emitted light was detected by an EMI 9558B photomultiplier perpendicular to the exciting light path. The fluorescence transients were recorded by a multichannel analyzer (ICA $70 \mathrm{KFKI}$ ).
Delayed Luminescence Measurements: For delayed luminescence measurements, algal cells were excited in a 1 $\mathrm{cm}$ cell as described by Hideg and Demeter (1985). The emitted light observed after opening of a Uniblitz shutter, was detected by an EMI 9558B photomultiplier. The signal was amplified and stored in the above mentioned multichannel analyzer connected to $\mathrm{X}-\mathrm{Y}$ recorder.

Thermoluminescence Measurements: Thermoluminescence measurements were carried out as described by Demeter and

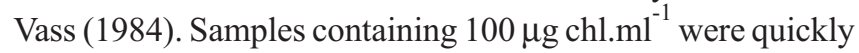
cooled to $-40^{\circ} \mathrm{C}$. The samples were illuminated with white light $\left(20 \mathrm{~W} . \mathrm{m}^{-2}\right)$ for $30 \mathrm{sec}$ before heating. Glow curves were then recorded between $-40^{\circ} \mathrm{C}$ and $60^{\circ} \mathrm{C}$ at a heating rate of $20^{\circ} \mathrm{C} \cdot \mathrm{min}^{-1}$.

\section{RESULTS}

Figure 1 shows the effect of $\mathrm{NaCl}$ treatment on the oxygen evolution and on partial reactions of photosynthetic electron transport. A $90 \%$ inhibition of whole chain oxygen evolution was observed at $0.5 \mathrm{~mol} . \mathrm{L}^{-1} \mathrm{NaCl}$. The measurements of PSIIactivated electron transport were carried out with DCQ as electron acceptor. It was strongly affected by increasing $\mathrm{NaCl}$ concentrations. At $0.5 \mathrm{~mol} . \mathrm{L}^{-1} \mathrm{NaCl}$ the inhibition was about $70 \%$ of the control. PSI-mediated electron transport from $\mathrm{DCPIPH}_{2}$ to methyl viologen was not affected by $\mathrm{NaCl}$ treatment in the applied concentration range. The flash lightinduced oxygen production was drastically decreased with increasing $\mathrm{NaCl}$ concentrations but the pattern of oscillation did not change (figure 2). Similar to the results obtained during constant illumination, 0.5 mol. $\mathrm{L}^{-1} \mathrm{NaCl}$ inhibited the steady state oxygen evolution by about $70 \%$ (figure 2 ). The inhibitory effect of $\mathrm{NaCl}$ on PSII-mediated electron transfer was in addition investigated by thermoluminescence measurements. Figure $3 \mathrm{~A}$ shows that the intensity of the $\mathrm{B}$ band is decreased with increasing $\mathrm{NaCl}$ concentrations and shifted by about $5^{\circ} \mathrm{C}$ from $25^{\circ} \mathrm{C}$ to $30^{\circ} \mathrm{C}$. After addition of DCMU (figure $3 \mathrm{~B}$ ) the intensity decreasing effect of $\mathrm{NaCl}$ can also be seen with the $\mathrm{Q}$ band. These results provide evidence that the $\mathrm{NaCl}$ treatment decreases PSII activity. The inhibitory action of $\mathrm{NaCl}$ on the water-splitting system of photosynthesis was also seen with measurements of fluorescence induction of $\mathrm{NaCl}$ treated cells. The $\mathrm{F}_{\mathrm{m}}$ level was markedly reduced (figure 4) but the $\mathrm{F}_{\mathrm{O}}$ level did not change, indicating a decrease of $\mathrm{F}_{\mathrm{V}}$ attributed to an inhibition of the electron flow at the water oxidizing side of PSII. Substitution of the inactivated water splitting system by the artificial electron donor $\mathrm{NH}_{2} \mathrm{OH}$ restored the fluorescence intensity to almost the control level (figure 5). This indicates that the action site of $\mathrm{NaCl}$ is before the $\mathrm{NH}_{2} \mathrm{OH}$ donation site and this is in agreement with our 
results drawn from the thermoluminescence investigation. Measurements of the delayed light emission kinetics (figure 6), which also is a measure for PSII charge recombination, are in agreement with the above finding. Figure 7 shows the oscillation pattern of the thermoluminescence B band as a function of excitation flash number. In the $\mathrm{NaCl}$-treated alga, the B band does not oscillate.

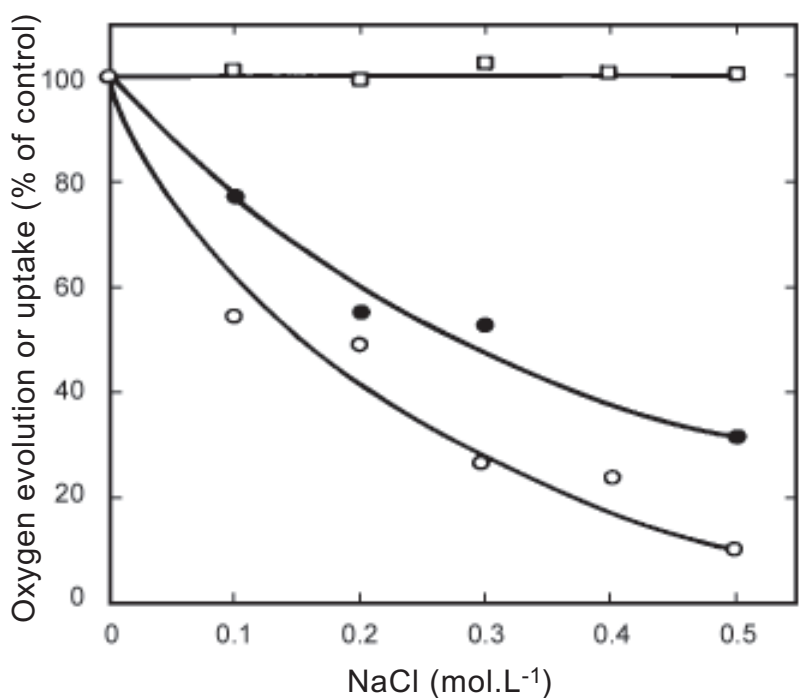

Figure 1. Effect of $\mathrm{NaCl}$ on various partial electron transport reactions of Chlorella vulgaris. Whole chain electron transport (O, open circle). PSI activity was measured from DCPIP $\left(40 \mu \mathrm{mol} . \mathrm{L}^{-1}\right)$ to $\mathrm{MV}\left(2 \mathrm{mmol} . \mathrm{L}^{-1}\right)$ in the presence of $10 \mu \mathrm{mol} . \mathrm{L}^{-1} \mathrm{DCMU}$ and $2 \mathrm{mmol} . \mathrm{L}^{-1}$ sodium ascorbate ( $\square$, open square). PSII activity was measured from $\mathrm{H}_{2} \mathrm{O}$ to $0.5 \mathrm{mmol} . \mathrm{L}^{-1} \mathrm{DCQ}(\bullet$, closed circle).

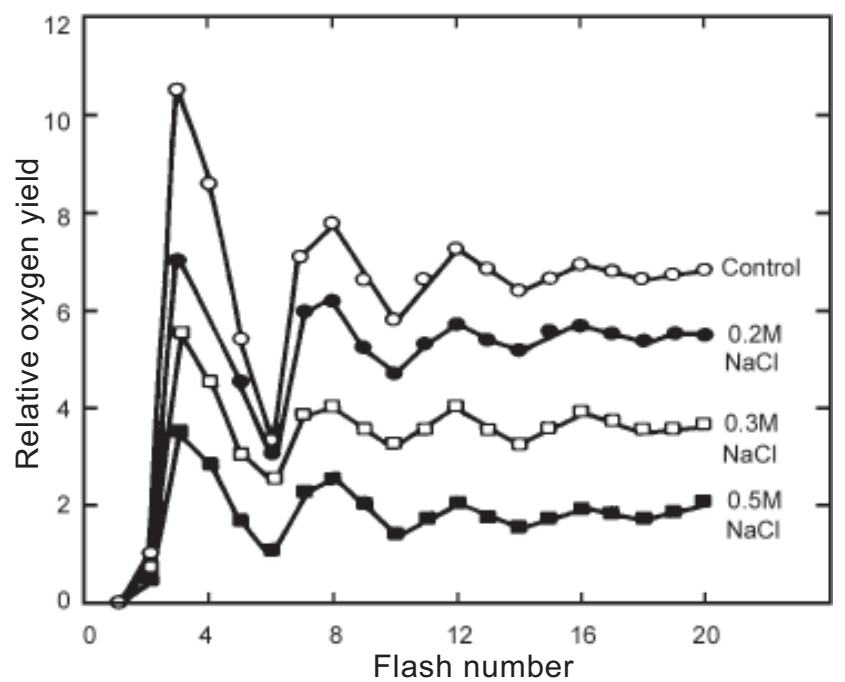

Figure 2. Effect of $\mathrm{NaCl}$ on the flash-induced oxygen yields of Chlorella vulgaris cells. After incubation with the salt, the cells were suspended in 50 mmol. $\mathrm{L}^{-1}$ phosphate buffer, $\mathrm{pH}$ 6.5 , containing $50 \mathrm{mmol} \cdot \mathrm{L}^{-1} \mathrm{KCl}$ and incubated in the dark on the surface of the electrode for $5 \mathrm{~min}$ before flash excitation.

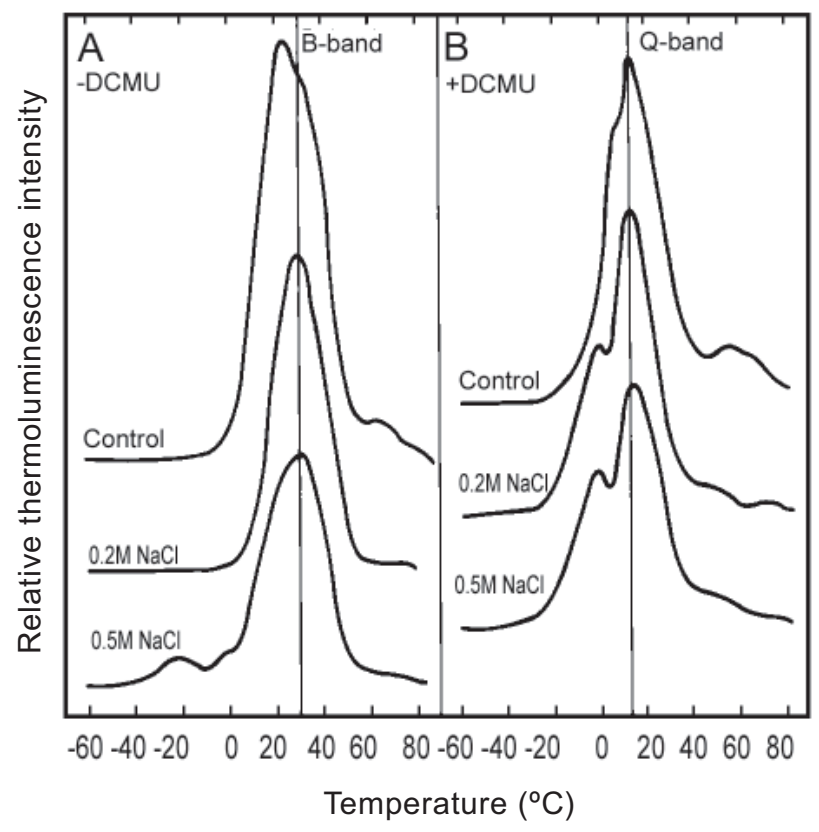

Figure 3. Effect of $\mathrm{NaCl}$ on the $\mathrm{Q}$ and $\mathrm{B}$ thermoluminescence bands of Chlorella vulgaris cells. Glow curves were obtained as described in Materials and Methods. The Q band was measured in the presence of $10 \mu \mathrm{mol}^{-\mathrm{L}^{-1}} \mathrm{DCMU}$. DCMU was added after incubation of the cells with the salt. The curves shown in the figures are representative of three independent measurements. (A) in the absence of DCMU, (B) in the presence of DCMU.

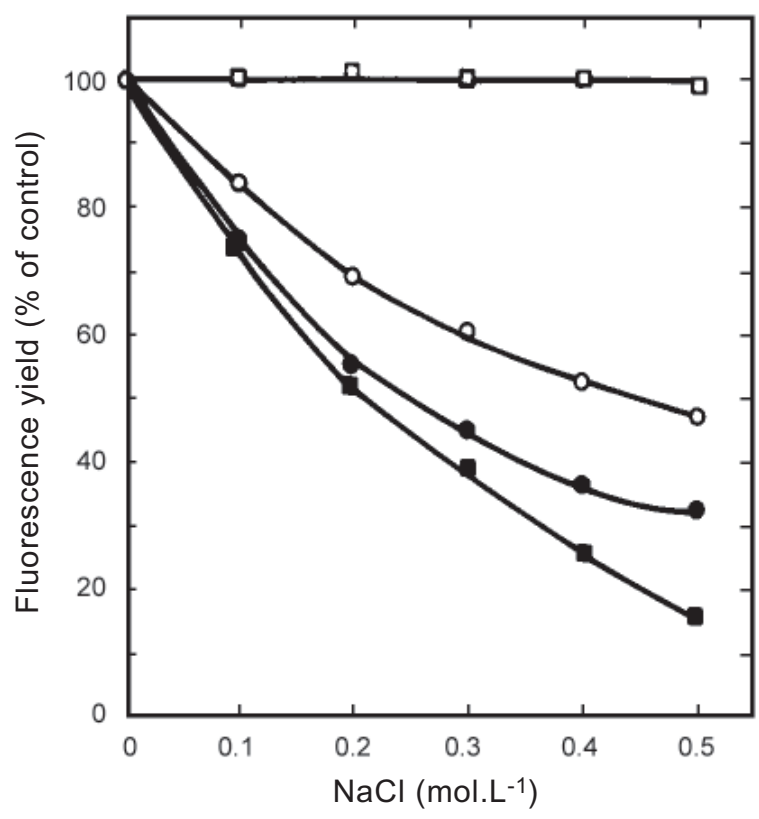

Figure 4. Effect of $\mathrm{NaCl}$ on the fluorescence induction transients of Chlorella vulgaris in the presence of DCMU, $\mathrm{F}_{\mathrm{m}}\left(\mathrm{O}\right.$, open circle), $\mathrm{F}_{\mathrm{V}}\left(\bullet\right.$, closed circle), $\mathrm{F}_{\mathrm{o}}(\square$, open square) and $F_{p}(\square$, closed square) in the absence of DCMU. 


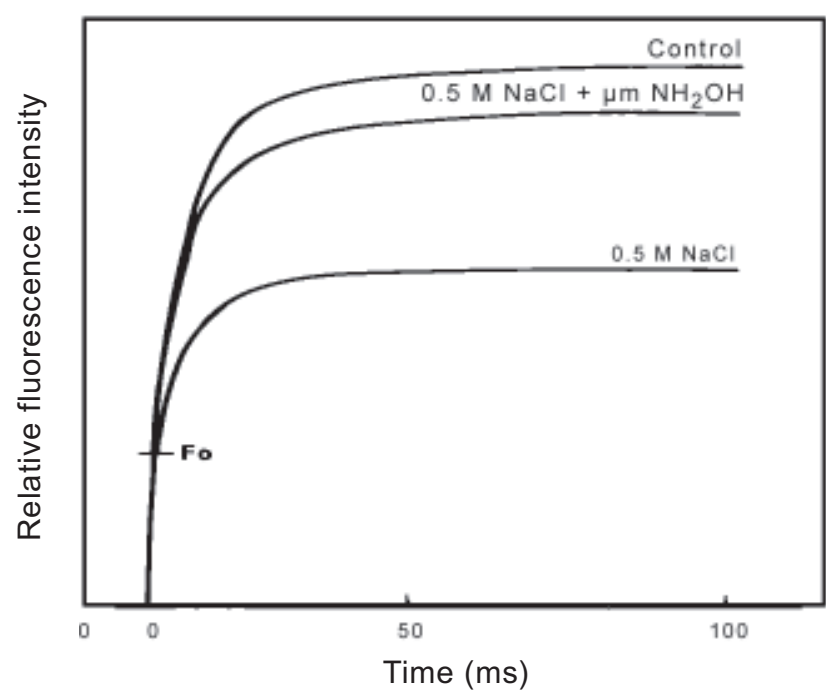

Figure 5. Fluorescence induction transient of untreated and $\mathrm{NaCl}$-treated Chlorella vulgaris cells and its restoration by the artificial electron donor, $20 \mu \mathrm{mol} . \mathrm{L}^{-1}$ hydroxylamine.

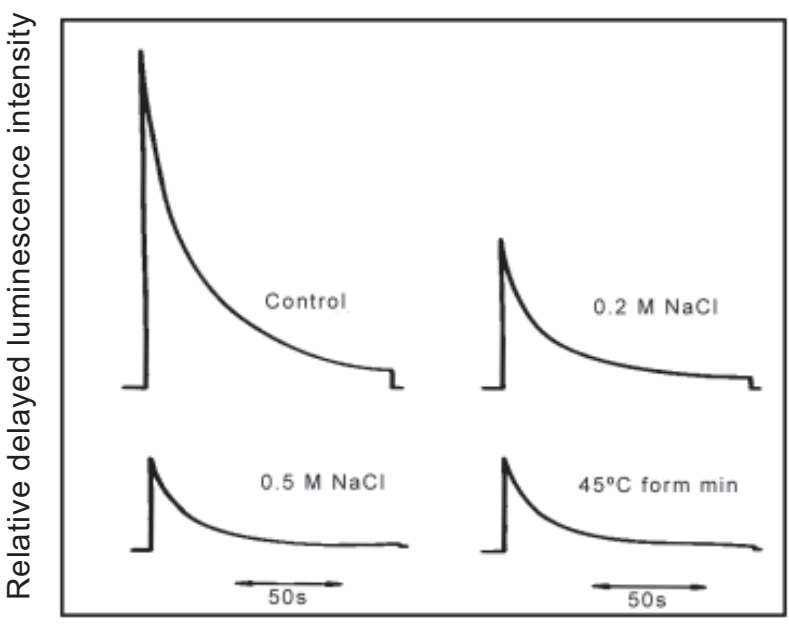

Time

Figure 6. Influence of $\mathrm{NaCl}$ and heat treatment on delayed luminescence of Chlorella vulgaris cells. The curves shown in the figures are representative of four repetitions.

\section{DISCUSSION}

The assay of the partial reaction of PSII using the artificial electron donor dichloro-p-benzoquinone indicated a rapid loss of oxygen evolution with increasing $\mathrm{NaCl}$ concentrations. However, the loss of PSI-mediated electron transport from $\mathrm{DCPIPH}_{2}$ to methyl viologen was not affected by $\mathrm{NaCl}$ treatments. The inhibitory effect of $\mathrm{NaCl}$ on PSII-mediated electron transfer was also investigated by the thermoluminescence (TL) studies. The B band originates from $\mathrm{S}_{2} \mathrm{Q}_{\mathrm{B}}{ }^{-}$and $\mathrm{S}_{3} \mathrm{Q}_{\mathrm{B}}{ }^{-}$charge recombination and the $\mathrm{Q}$ band originates from $\mathrm{S}_{2} \mathrm{Q}_{\mathrm{A}}{ }^{-}$charge recombination in the presence of DCMU (Demeter and Govindjee, 1989; Vass and Inoue,

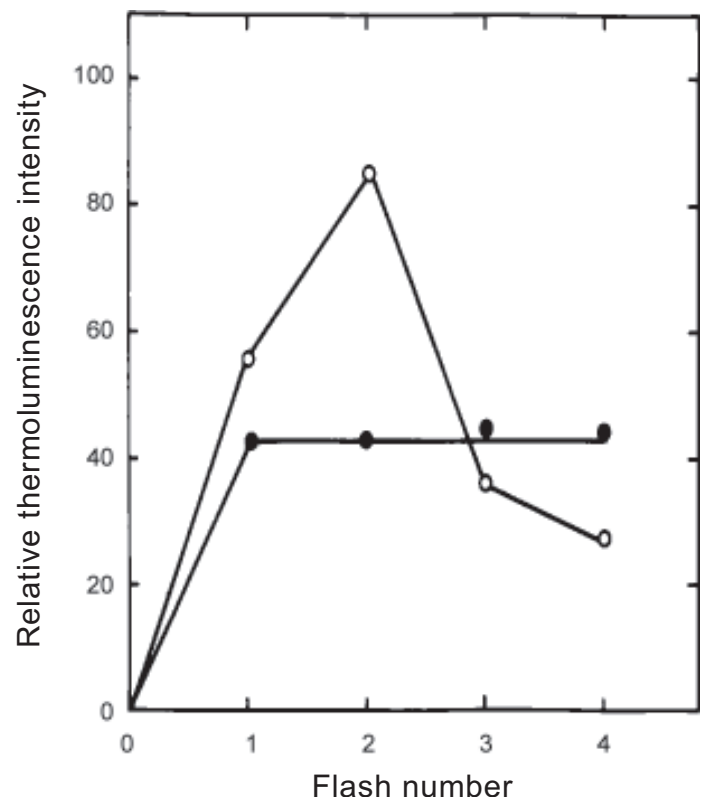

Figure 7. Oscillation of flash-induced thermoluminescence B band in control (O, open circle) and $0.5 \mathrm{~mol} . \mathrm{L}^{-1} \mathrm{NaCl}$-treated (๑, closed circle) Chlorella vulgaris. Dark-adapted samples $\left(5 \mathrm{~min}\right.$ ) were illuminated with a series of flashes at $-5^{\circ} \mathrm{C}$ and cooled quickly to $-60^{\circ} \mathrm{C}$ and the $\mathrm{B}$ band was recorded as described in the Materials and Methods.

1992). The magnitude of the two bands is diminished by $\mathrm{NaCl}$ treatments and this result supports the inhibitory effect of $\mathrm{NaCl}$ on PSII. Fluorescence induction was used to probe the pattern of inhibition (Murphy et al. 2003). In algal cells treated with different $\mathrm{NaCl}$ concentrations, both the maximum fluorescence $\left(\mathrm{F}_{\mathrm{m}}\right)$ and the variable fluorescence $\left(\mathrm{F}_{\mathrm{v}}\right)$ was markedly reduced. A decrease in fluorescence yield of the intact algae cells can be attributed to an inhibition of the electron flow at the oxidizing side of PSII (Lu and Vonshak, 2002). Substitution of the inactivated water splitting system by an artificial electron donor $\mathrm{NH}_{2} \mathrm{OH}$ (Canaani et al. 1986), restored the fluorescence intensity almost to the initial control. This result demonstrates that the action site of $\mathrm{NaCl}$ is before the $\mathrm{NH}_{2} \mathrm{OH}$ donation site. In this connection, $\mathrm{Lu}$ and Vonshak (2002) indicated that 0.8 mol. $\mathrm{L}^{-1} \mathrm{NaCl}$ decreased oxygen evolution which correlated with the decrease in the quantum yield of the PSII electron transport. They also suggested that salinity stress resulted in a decrease in the efficiency of electron transfer from $\mathrm{Q}_{\mathrm{A}}{ }^{-}$to $\mathrm{Q}_{\mathrm{B}}$. Delayed light emission is the result of charge reactions in PSII (Lavorel, 1975). The effect of heat, which is well known to inhibit the water splitting system, is comparable with the effect of $\mathrm{NaCl}$ and a similar decrease in the amplitude of delayed light emission was obtained. This result suggests that $\mathrm{NaCl}$ inhibits the electron 
transport process at the water splitting system. GonzalesMorono et al. (1997) also suggested that $\mathrm{NaCl}$ induced a drop in the $\mathrm{HCO}_{3}{ }^{-}$- dependent water splitting activity of PSII of Euglena gracilis. The assignment of the $\mathrm{B}$ and $\mathrm{Q}$ thermoluminescence bands to the $\mathrm{S}_{2} / \mathrm{S}_{3} \mathrm{Q}_{\mathrm{B}}{ }^{-}$and $\mathrm{S}_{2} / \mathrm{Q}_{\mathrm{A}}{ }^{-}$ recombination, respectively, opens up a new perspective in the study of both the water splitting system and the primary and secondary quinine acceptors. Since the $\mathrm{S}$ states participate in the generation of the B band, the oscillatory behavior of the $\mathrm{B}$ band provides an unique opportunity to investigate the transition of S states even if oxygen evolution is inhibited. In the salt-treated alga, the TL intensity could be changed by the first flash, but subsequent flashes did not change TL intensity. Since the water splitting system is in the $\mathrm{S}_{2}$ state after the first flash, it can be concluded that $\mathrm{NaCl}$ inhibited the $\mathrm{S}_{2} \rightarrow \mathrm{S}_{3}$ transition of the water splitting system. These results confirm the assumption that the mechanism of $\mathrm{NaCl}$ inhibition of PSII in the in vivo system at the low salt concentrations (0.1-0.5 mol. $\left.\mathrm{L}^{-1}\right)$ used in this investigation is the same as has been observed by $\mathrm{NaCl}$ in in vitro experiments at high salt concentrations (1-2 mol.L $\left.\mathrm{L}^{-1}\right)$.

\section{REFERENCES}

Booth WA and Beardall J (1991) Effect of salinity on inorganic carbon utilization and carbonic anhydrase activity in the halotolerant alga Dunaliella salina (Chlorophyta). Physiologia 30:220-225.

Canaani O Havaux M and Malkin S (1986) Hydroxylamine, hydrazine and methylamine donate electrons to the photoxidizing side of photosystem II in leaves inhibited in oxygen evolution due to water stress. Biochim. Biophys. Acta 851:151-155.

Chen CS and Plant AL (1999) Salt induced protein synthesis in Tomato roots. J. Exp. Bot. 50:677-687.

Demeter S and Govindjee (1989) Thermoluminescence in plants. Physiol. Plant. 75:121-130.

Demeter S and Vass I (1984) Charge accumulation and recombination in photosystem II studied by thermoluminescence I. Participation of the primary acceptor Q and secondary acceptor B in the generation of thermoluminescence in chloroplasts. Biochim. Biophys. Acta 764:24-32.

EL-Sheekh MM (1990) The systematic position of some algal taxa and the effect of some environmental factors on cell wall composition. Ph.D. thesis, Tanta University, Egypt.

EL-Sheekh MM and Omar HH (2002) Effect of high salt stress on growth and fatty acids content of the unicellular green alga Chlorella vulgaris. Az. J. Microbiol. 55:181-191.

Gonzalez-Moreno S Gomez-Berrera J Perales H and Monerono-Sanchez R (1997) Multiple effects of salinity on photosynthesis of the protist Euglena gracilis. Physiol. Plant. 101:777-786.

Guillard RRL (1962) Salt and osmotic balance. In: Lewin (ed) Physiology and Biochemistry of Algae, pp 529-540. Academic Press, New York.
Hideg E and Demeter S (1985) Binary oscillation of delayed luminescence: evidence for participation of $\mathrm{Q}_{\mathrm{B}}{ }^{-}$in the charge recombination. Z. Naturforsch. 40c:827-831.

Joset F Jeanjean R and Hageman N (1996) Dynamics of the response of the cyanobacteria to salt stress: Deciphering the molecular events. Physiol. Plant. 96:738-744.

Kuhl A(1962) Zur physiologie der speicherung kondensertieren organischer phosphate in Chlorella. In: Beiträge zur physiologie und morphologie der algen, Gustav Fischer Verlag, Stuttgart, Germany.

Lartigue J Neill A Hayden BL Pulfer J and Cebrian J (2003) The impact of salinity fluctuations on net oxygen production and inorganic nitrogen uptake by Ulva lactuca (Chlorophyceae). Aquat. Bot. 75:339-350.

Lavorel I (1975) Luminescence. In: Govindjee (ed) Bioenergetics of Photosynthesis, pp 225-317. Academic Press, New York.

Lu CM and Torzillo G and Vonshak A (1999) Kinetic response of photosystem II photochemistry in the cyanobacterium Spirulina platensis to high salinity is characterized by two distinct phases. Austr. J. Plant Physiol. 26:283-292.

Lu CM and Vonshak A (1999) Characterization of PS II photochemistry in salt-adapted cells of the cyanobacterium Spirulina platensi. New Phytol. 141:231-239.

Lu CM and Vonshak A (2002) Effects of salinity stress on photosystem II function in cyanobacterial Spirulina platensis cells. Physiol. Plant. 114:405-413.

Lu CM and Zhang JH (1999) Effects of salt stress on PS II function and photoinhibition in the cyanobacterium Spirulina platensis J. Plant Physiol. 155:740-745.

Lu CM and Zhang JH (2000) Role of the light in the response of PS II photochemistry to salt stress the cyanobacterium Spirulina platensi. J. Exp. Bot. 51:911-917.

Moisnder PH McClinton E and Paer HW (2002) Salinity effects on growth, photosynthetic parameters, and nitrogenase activity in estuarine planktonic cyanobacteria. Microb. Ecol. 43:432-442.

Murakami A Kim SJ and Fujita Y (1997) Changes in photosystem stoichiometry in response to environmental conditions for cell growth observed with the cyanophyte Synechocystis PCC 6714. Plant Cell Physiol. 38:392-7.

Murphy Kinsey ST and Durako MJ (2003) Physiological effects of short-term salinity changes on Ruppia maritime. Aquat. Bot. 75:293-309.

Seemann JR and Critchley C (1985) Effect of salt stress on the growth, ion content, stomatal behavior and photosynthetic capacity of a salt-sensitive species, Phaseolus vulgaris L. Planta 164:151-162.

Sharma PK and Hall DO (1991) Interaction of salt stress and photoinhibition on photosynthesis in barley and sorghum. J. Plant Physiol. 138:614-619.

Shen J-R Katoh S (1991) Inactivation and calcium-dependent reactivation of oxygen evolution in photosystem II preparations treated at $\mathrm{pH} 3.0$ or with high concentration of NaCl. Plant Cell Physiol. 32:439-446.

Vass I and Inoue Y. (1992) Thermoluminescence in the study of photosystem II. In: Barber J (ed) The Photosystems: Structure, Function and Molecular Biology. pp 259-249. Elsevier Science Publishers. 